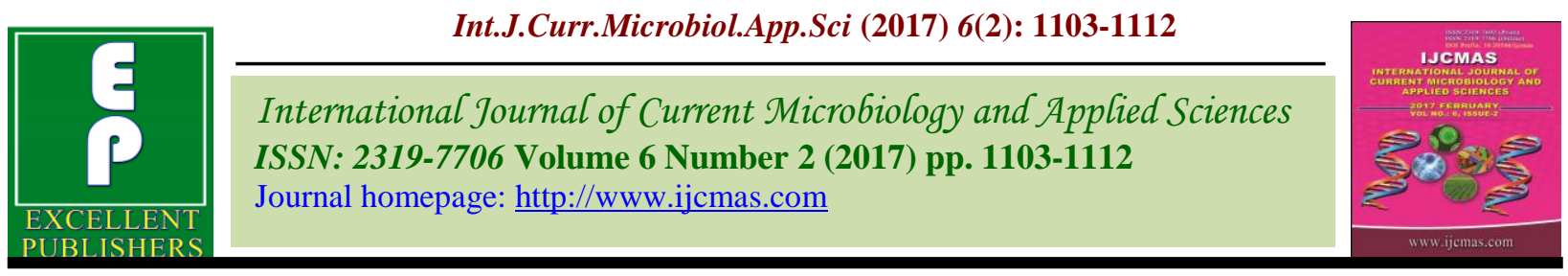

Original Research Article

http://dx.doi.org/10.20546/ijcmas.2017.602.124

\title{
Identification and Characterization of Lactobacillus isolates from fermented soya food "Tungrymbai", Meghalaya, India
}

\author{
Birendra Kumar Mishra ${ }^{1}$, Subrota Hati ${ }^{2 *}$, Sujit Das ${ }^{1}$ and Keyur Patel ${ }^{2}$ \\ ${ }^{1}$ Department of Rural Development and Agricultural Production, North-Eastern Hill University, \\ Tura campus, Meghalaya-794 001, India \\ ${ }^{2}$ Dairy Microbiology Department, S.M.C. College of Dairy Science, Anand Agricultural \\ University, Anand-388 110, India \\ *Corresponding author
}

\section{A B S T R A C T}

Keywords

Tungrymbai, Lactobacillus, Soy foods, API, NCBI, 16SrDNA.

Article Info

Accepted:

20 January 2017

Available Online:

10 February 2017
Tungrymbai is one of the most popular and ethnic fermented food of Garo and Khasi tribes of Meghalaya region, produced by fermentation of soya beans by heterogeneous Lactic Acid Bacteria. To assess the nature of microbes and their source during spontaneous fermentation is generally studied to explore the microbial diversity of this particular food. In this era, lactic acid bacteria has drawn maximum attention in food and nutrition science due to their nutraceutical potential producing certain biologically active peptides, along with other functional and probiotic attributes and most importantly having GRAS status. In the present investigation, isolates were screened on MRS medium, Lactobacillus strains were identified by phenotypic (Gram staining, catalase activity and API test) and genotypic by molecular characterization (PCR). Phylogenetic tree of the most closely related Lactobacillus species has been constructed by using MAFFT sequence alignment tool. Sequences are deposited in GeneBank and NCBI bearing the accession number.

\section{Introduction}

Tungrymbai is an ethnic fermented indigenous soya food popular to the Khasi and Garo tribes of Meghalaya. Lactobacillus along with other lactic acid bacteria's are its natural habitat (Thockhom and Joshi, 2012). Tungrymbai is a naturally fermented soybean food eaten as a side dish in Meghalaya state of India (Tamanget al., 2009). It forms an intricate part of the diet and serves as a cheap source of high protein food in local diet. The protein content in Tungrumbai has been found to be $45.9 \mathrm{~g} \%$ on a dry weight basis. Whereas, fat, fibre and ash have been found to be $30.2,12.8$ and $5.5 \mathrm{~g} \%$ respectively (Agrahar-Murungkar and Subbulakshmi, 2006). It is a sticky food that exhibits its unique flavor and texture that may not be palatable to everyone. During its preparation, local varieties of soybean seeds are washed, soaked for about 4-6 h, the outer skin is removed by rubbing gently between the palms and is cooked (1-2 h) until all the water is absorbed and the soybeans can be pressed easily. The cooked beans are allowed to cool, and are packed with leaves of Clinogyne dichotoma or Phrynium pubinerve lined in the 
bamboo basket and covered by a thick cloth or jute bag. The covered basket is kept near the fireplace $\left(25-40{ }^{\circ} \mathrm{C}\right)$ for natural fermentation for 3-5 days to get a sticky product.

Proper identification and characterization of lactobacilli is not only done by phenotypic methods but it includes molecular studies as well. Molecular studies focuses on DNA sequencing and sequence analysis of evolutionary stable genes to study bacterial phylogeny and diversity (Tringe and Hugenholtz, 2008). For this purpose, genes that code for the $5 \mathrm{~S}$, the $16 \mathrm{~S}$, the $23 \mathrm{~S}$ rRNA and spaces between these genes are supposed to be potential candidates. Among these the most common part of the DNA used for taxonomic purposes is the $16 \mathrm{~S}$ rRNA gene (Harmsen and Karch, 2004; Tortoliet al., 2003; Palyset al., 1997) due to its highly conserved nature among three regions, (Clarridgeet al., 2004) hence, the 16S rRNA gene is universal in bacteria, and so relationships can be measured among all bacteria (Woese and Stackebrandt, 1985; Woeseet al., 1987). Major application of 16S sequence analysis is identification, classification and estimation of bacterial diversity of isolated pure culture along with environmental samples without culturing through metagenomic approaches (Rajendhran and Gunasekarsan, 2011).

Different studies on probiotic potential of Lactobacillus has been conducted previously focusing on its isolation, acid and bile tolerance and antimicrobial properties but molecular level study of isolates from fermented soy foods has not been explored yet. Keeping in view the potential health benefits and nutraceutical properties of probiotics, this study is designed to explore novel lactic acid bacteria, particularly, Lactobacillus sp. from ethnic fermented soya food, "Tungrymbai" up to molecular level characterization along with phylogenetic studies. In Meghalaya, this study will help to provide a more valuable functional food with particular health benefits. The aim of this paper is to isolate and identify the predominant species of Lactobacillus in naturally fermented Tungrymbai of Meghlaya, India. These species were characterized using phenotypic and molecular techniques for confirmation of genus and species level of Lactobacillus strains, along with DNA sequencing and analysis of phylogenetic studies by utilizing $16 \mathrm{~S}$ rRNA gene.

\section{Materials and Methods}

\section{Sample collection and bacterial growth enrichment}

Homemade and commercial samples of fermented soya (Tungrymbai) were collected from different region of Meghalaya state and included in this investigation (Table 1). The enrichment process was carried out by inoculating approximately $1 \mathrm{ml}$ of a mix of the liquor and poured into $50 \mathrm{ml}$ sterile MRS broth (HiMedia, India) and incubated at $37^{\circ} \mathrm{C}$ for (2-5) days (Abbas and Mahasneh, 2014). All samples were collected into sterile glass bottles and were kept in the laboratory at refrigeration temperature $\left(4-6^{\circ} \mathrm{C}\right)$ for further analysis.

\section{Identification of bacterial strains}

All isolates were tested for catalase activity, Gram reaction and cell morphology (Guessas and Khal, 2004). The identification of strains was performed according to their morphological, cultural and biochemical properties based on their specific characteristics as described in Bergy's manual (Buchanan and Gibbons, 1974). The strains were tested for the production of acids from carbohydrates and related compounds using API $50 \mathrm{CH}$ kits (HiMedia, India) according to 
the manufacturer's instructions. Results were scored after incubation at $37^{\circ} \mathrm{C}$ for 24 and 48 hours. These results were puton the apiweb ${ }^{\mathrm{TM}}$ identification software with database (V5.1) which uses the phenotypic data to predict a species identity. Interpretations of the fermentations profiles were facilitated by comparing all results obtained for the tested isolates with information from the computer aided database, apiweb ${ }^{\mathrm{TM}}$ (https://apiweb.biomerieux.com).

\section{Confirmation of lactobacilli isolates by colony PCR}

Molecular characterization of isolates was done by Polymerase Chain Reaction (PCR) using primers (27F and 1492R) (Table 2). Template was prepared by picking freshly grown colony and transferred to TE buffer and incubate at $80^{\circ} \mathrm{C}$ for 15 minutes. This was further amplified by PCR and confirmed by running product on agarose gel $(1 \%)$ in gel electrophoresis. PCR mixture was initially heated at $94^{\circ} \mathrm{C}$ for 5 minutes followed by cycles of denaturation at $94^{\circ} \mathrm{C}$ for $1 \mathrm{~min}$, annealing $56^{\circ} \mathrm{C}$ for $1 \mathrm{~min}$ and extension was performed at $72^{\circ} \mathrm{C}$ for 5 minutes.

\section{Results and Discussion}

This study was conducted to isolate Lactobacillus strains from ethnic fermented soya food "Tungrymbai" from the various places of Meghalaya (North-eastern region of India) and explore their phenotypic and genotypic characteristics for further, development of value added products by identifying productive microbial strains.

\section{Phenotypic characterization Lactobacillus strains}

A total of three strains were isolated from the various samples of Tungrymbai obtained from different places of Meghalaya, India (Table
1). Three catalase negative and Gram positive bacteria were isolated from fermented soya foods and considered as presumptive LAB (Figure 1). Further, biochemical tests of all the isolates were carried out by API CH 50 Microbial Identification kit (bioMerieux, India)through sugar fermentation pattern, ammonia production from arginine, gas production from glucose were carried out for the initial characterisation of lactic acid bacteria isolated from the samples.

From the table 3, the isolates, both RD10 and K20 showed negative whereas the isolate, K38A showed positive results for D-mannitol, D-mannose, Methyl- $\alpha$-D-mannopyranoside, Amygdalin, Arbutin, Salicin, D-lactose, Draffinose, D-celiobiose, Gentibiose respectively. RD10 and K38A showed positive whereas K20 showed negative results for tests like L-arabinose, D-ribose, and Dgalactose. K20 and K38A showed positive whereas RD10 showed negative results for Dmaltose, D-saccharose, D-glucose, and Dtrehalose respectively. K20 and K38A showed negative whereas RD10 showed positive for $\mathrm{D}$-xylose, potassium gluconate, potassium-2-ketogluconate, and potassium-5ketogluconate respectively. All the three isolates were able able to utilize esculin ferric citrate, n-acetyl glucosamine, D-fructose, resulting to be positive and were not able to utilize glycerol, erythritol, D-arabinose,LXylose, D-Adonitol, Methyl- $\beta$-DXylopyranoside, D-sorbitol, L-Sorbose,LRhomnose, Dulcitol, Inositol, Inulin, Methyl $\alpha$-D-Glucopyranoside, D-Turanose, DLyxose, D-Tagatose, D-Fucose, L-Fucose, DArbitol, L-Arbitol thereby resulting to be negative respectively (Table 3 ).

Hence, from the above biochemical tests it was assumed that all the three isolates belonged to the group of heterofermentative lactic acid bacteria. The tentative identification by using API $50 \mathrm{CH}$ was in 
good concordance with those by the genetic identification which later on showed that RD10 and K38A belongs to Lactobacillus brevis and K20 belongs to Lactobacillus fermentum (Figure 2).

Molecular confirmation and 16S rDNA sequence analysis of Lactobacillus strains

Easiest and simplest way for identification of LAB is amplification of $16 \mathrm{~S}$ rRNA, 16S-23S intergenic spacer region (ISR), or 23S rRNA universal gene by designing specific primers (Kimet al., 2005). In the present study, primer $27 \mathrm{~F}$ and $1492 \mathrm{R}$ were used for amplification conserved regions of $16 \mathrm{~S}$ rRNA, resulted in product of $1.5 \mathrm{~kb}$ fragments confirming that the isolate bacteria was from genus Lactobacillus. Rahayu et al., 2009 used same primers set for amplification of bacterial $16 \mathrm{~S}$ rRNA gene and reported the PCR product of $1.5 \mathrm{kbs}$. The electrophenogram data for $16 \mathrm{~S}$ rDNA sequence was validated using Chromas 2.33 software. Sequences obtained were matched with previously published bacterial $16 \mathrm{~S}$ rDNA sequences available in the GenBank database using BLAST. The sequences determined in this study have been deposited in the NCBIGenBank database with accession numbers (Table 4).

The FASTA sequences of the identified strains after 16S rDNA sequence analysis are as follows:

\section{6s rRNA sequence of Lactobacillus brevis (GeneBank Accession no.KX572212)}

>gi|1044329733|gb|KX572212.1| Lactobacillus sp. strain brevis RD10 16S ribosomal RNA gene, partial sequence AGCTTCCGTTGAATGACGTGCTTGCACTGATTTTAACAATGAAGCGAGTGGCGAACTGGTGAGT AACACGTGGGAAATCTGCCCAGAAGCAGGGGATAACACTTGGAAACAGGTGCTAATACCGTATA ACAACAAAGTCCGCATGGATTTTGTTTGAAAGGTGGCTTCGGCTATCACTTCTGGATGATCCCG CGGCGTATTAGTTAGTTGGTGAGGTAAAGGCCCACCAAGACGATGATACGTAGCCGACCTGAGA GGGTAATCGGCCACATTGGGACTGAGACACGGCCCAAACTCCTACGGGAGGCAGCAGTAGGGAA TCTTCCACAATGGACGAAAGTCTGATGGAGCAATGCCGCGTGAGTGAAGAAGGGTTTCGGCTCG TAAAACTCTGTTGTTAAAGAAGAACACCTTTGAGAGTAACTGTTCAAGGGTTGACGGTATTTAA CCAGAAAGCCACGGCTAACTACGTGCCAGCAGCCGCGGTAATACGTAGGTGGCAAGCGTTGTCC GGATTTATTGGGCGTAAAGCGAGCGCAGGCGGTTTTTTAAGTCTGATGTGAAAGCCTTCGGCTT AACCGGAGAAGTGCATCGGAAACTGGGAGACTTGAGTGCAGAAGAGGACAGTGGAACTCCATGT GTAGCGGTGGAATGCGTAGATATATGGAAGAACACCAGTGGCGAAGGCGGCTGTCTAGTCTGTA ACTGACGCTGAGGCTCGAAAGCATGGGTAGCGAACAGGATTAGATACCCTGGTAGCCATGCCGT AAACGATGAGTGCTA

\section{6s rRNA sequence of Lactobacillus fermentum (GeneBank Accession no.KU644579)}

>gi|999867666|gb|KU644579.1| Lactobacillus fermentum strain K20 $16 \mathrm{~S}$ ribosomal RNA gene, partial sequence CTCCATCCAGTGGTGATCGGGTGAGTCCCACGTTTGTAACCTGCCCAGAAGCGGGGGACAACAT TTGGAAACAGACGCTAATACCGCATAACAGCGCCGCTCGCATGAACAACGCTCATACGATGGCT TCTCGCTATCACTTCTGGATGGACCTGCGGTGCATTAACTTGTTGGCGCGGTAAAGGCCTACCA AgGCCACGATGCATATCCGTGTTTAAAGACCGCTCGGCCACTATGTGATTGACACACATCCCAT ACTCCTACGGGAGGCAGCAGTAGGGAATCTTCCACAATGGGCGCAAGCCTGATGGAGCAACACC GCGTGAGTGAAGAAGGGTTTCGGCTCGTAAAGCTCTGTTGTTAAAGAAGAACACGTATGAGAGT 
Int.J.Curr.Microbiol.App.Sci (2017) 6(2): 1103-1112

AACTGTTCATACGTTGACGGTATTTAACCAGAAAGTCACGGCTAACTACGTGCCAGCAGCCGCG GTAATACGTAGGTGGCAAGCGTTATCCGGATTTATTGGGCGTAAAGAGAGTGCAGGCGGTTTTC TAAGTCTGATGTGAAAGCCTTCGGCTTAACCGGAGAAGTGCATCGGAAACTGGATAACTTGAGT GCAGAAGAGGGTAGTGGAACTCCATGTGTAGCGGTGGAATGCGTAGATATATGGAAGAACACCA GTGGCGAAGGCGGCTACCTGGTCTGCAACTGACGCTGAGACTCGAAAGCATGGGTAGCGAACAG GATTAGATACCCTGGTAGTCCATGCCGTAAACGATGAGTGCTAGGTGTTGGAGGGTTTCCGCCC TTCAGTGCCGGAGCTAACGCATTAAGCACTCCGCCTGGGGAGTACGACCGCAAGGTTGAAACTC AAAGGAATTGACGGGGGCCCGCACAAGCGGTGGAGCATGTGGTTTAATTCGAAGCTACGCGAAG AACCTTACCAGGTCTTGACATCTTGCGCCAACCCTAGAGATAGGGCGTTTCCTTCGGGAACGCA ATGACAGGTGGTGCATGGTCGTCGTCAGCTCGTGTCGTGAGATGTTGGGTTAAGTCCCGCAACG AGCGCAACCCTTGTTACTAGTTGCCAGCATTAAGTTGGGCACTCTAGTGAGACTGCCGGTGACA AACCGGAGGAAGGTGGGGACGACGTCAGATCATCATGCCCCTTATGACCTGGGCTACACACGTG CTACAATGGACGGTACAACGAGTCGCGAACTCGCGAGGGCAAGCAAATCTCTTAAAACCGTTCT CAGTTCGGACTGCAGGCTGCAACTCGCCTGCACGAAGTCGGAATCGCTAGTAATCGCGGATCAG CATGCCGCGGTGAATACGTTCCCGGGCCTTGTACACACCGCCCGTCACACCATGAGAGTTTGTT ACACCCAAAGTCGGTGGGGTAACCT

\section{6s rRNA sequence of Lactobacillus brevis (GeneBank Accession no.KU529283)}

>gi|978128123|gb|KU529283.1| Lactobacillus brevis strain K38A $16 \mathrm{~S}$ ribosomal RNA gene, partial sequence ACGTGCTTGCACTGATTTCAACAATGAAGCGAGTGGCGAACTGGTGAGTAACACGTGGGGAATC TGCCCAGAAGCAGGGGATAACACTTGGAAACAGGTGCTAATACCGTATAACAACAAAATCCGCA TGGATTTTGTTTGAAAGGTGGCTTCGGCTATCACTTCTGGATGATCCCGCGGCGTATTAGTTAG TTGGTGAGGTAAAGGCCCACCAAGACGATGATACGTAGCCGACCTGAGAGGGTAATCGGCCACA TTGGGACTGAGACACGGCCCAAACTCCTACGGGAGGCAGCAGTAGGGAATCTTCCACAATGGAC GAAAGTCTGATGGAGCAATGCCGCGTGAGTGAAGAAGGGTTTCGGCTCGTAAAACTCTGTTGTT AAAGAAGAACACCTTTGAGAGTAACTGTTCAAGGGTTGACGGTATTTAACCAGAAAGCCACGGC TAACTACGTGCCAGCAGCCGCGGTAATACGTAGGTGGCAAGCGTTGTCCGGATTTATTGGGCGT AAAGCGAGCGCAGGCGGTTTTTTAAGTCTGATGTGAAAGCCTTCGGCTTAACCGGAGAAGTGCA TCGGAAACTGGGAGACTTGAGTGCAGAAGAGGACAGTGGAACTCCATGTGTAGCGGTGGAATGC GTAGATATATGGAAGAACACCAGTGGCGAAGGCGGCTGTCTAGTCTGTAACTGACGCTGAGGCT CGAAAGCATGGGTAGCGAACAGGATTAGATACCCTGGTAGTCCATGCCGTAAACGATGAGTGCT AAGTGTTGGAGGGTTTCCGCCCTTCAGTGCTGCAGCTAACGCATTAAGCACTCCGCCTGGGGAG TACGACCGCAAGGTTGAAACTCAAAGGAATTGACGGGGGCCCGCACAAGCGGTGGAGCATGTGG TTTAATTCGAAGCTACGCGAAGAACCTTACCAGGTCTTGACATCTTCTGCCAATCTTAGAGATA AGACGTTCCCTTCGGGGACAGAATGACAGGTGGTGCATGGTTGTCGTCAGCTCGTGTCGTGAGA TGTTGGGTTAAGTCCCGCAACGAGCGCAACCCTTATTATCAGTTGCCAGCATTCAGTTGGGCAC TCTGGTGAGACTGCCGGTGACAAACCGGAGGAAGGTGGGGATGACGTCAAATCATCATGCCCCT TATGACCTGGGCTACACACGTGCTACAATGGACGGTACAACGAGTCGCGAAGTCGTGAGGCTAA GCTAATCTCTTAAAGCCGTTCTCAGTTCGGATTGTAGGCTGCAACTCGCCTACATGAAGTTGGA ATCGCTAGTAATCGCGGATCAGCATGCCGCGGTGAATACGTTCCCGGGCCTTGTACACACCGCC CGTCACACCATGAGAGTTTGTAACACCCAAAGCCGG 
Table.1 List of selected isolates with their phenotypical characterization

\begin{tabular}{|l|l|l|l|l|l|l|l|}
\hline S.No. & $\begin{array}{c}\text { Fermented } \\
\text { Food } \\
\text { Sample }\end{array}$ & $\begin{array}{c}\text { Traditional } \\
\text { name of } \\
\text { collected } \\
\text { fermented } \\
\text { food } \\
\text { sample(s) }\end{array}$ & $\begin{array}{c}\text { Place of } \\
\text { purchased } \\
\text { fermented } \\
\text { food } \\
\text { sample(s) }\end{array}$ & $\begin{array}{c}\text { Isolate } \\
\text { Code }\end{array}$ & $\begin{array}{l}\text { Morphological } \\
\text { characteristics }\end{array}$ & $\begin{array}{c}\text { Gram's } \\
\text { Reaction }\end{array}$ & $\begin{array}{c}\text { Microscopic } \\
\text { Examination }\end{array}$ \\
\hline 1 & $\begin{array}{l}\text { Fermented } \\
\text { Soybean }\end{array}$ & Tungrymbai & $\begin{array}{l}\text { Nongkrem, } \\
\text { Shillong }\end{array}$ & RD10 & $\begin{array}{l}\text { Small, oval, } \\
\text { white }\end{array}$ & + ve & Bacilli \\
\hline 2 & $\begin{array}{l}\text { Fermented } \\
\text { Soybean }\end{array}$ & Tungrymbai & $\begin{array}{l}\text { Tikrikela, } \\
\text { Garo Hills }\end{array}$ & K38A & $\begin{array}{l}\text { Pinpoint, } \\
\text { Transparent }\end{array}$ & + ve & $\begin{array}{l}\text { Short thick } \\
\text { rods }\end{array}$ \\
\hline 3 & $\begin{array}{l}\text { Fermented } \\
\text { Soybean }\end{array}$ & Tungrymbai & $\begin{array}{l}\text { Asanang, } \\
\text { Garo Hills }\end{array}$ & K20 & $\begin{array}{l}\text { Pinpoint, } \\
\text { transperant }\end{array}$ & + ve & Bacilli \\
\hline
\end{tabular}

Table.2 Oligonucleotide sequences for PCR amplification

\begin{tabular}{|c|c|}
\hline \multicolumn{2}{|c|}{ Primers } \\
\hline $27 \mathrm{~F}$ & 5' TACGGYTACCTTGTTACGACTT 3' \\
\hline 1492 R & 5' AGAGTTTGATCAMTGGCTCAG 3' \\
\hline
\end{tabular}

Table.3 Biochemical tests of screened isolates through API 50CH kit

\begin{tabular}{|c|c|c|c|c|}
\hline \multicolumn{2}{|c|}{ API 50 CH } & RD10 & K38A & K20 \\
\hline 0 & Control & - & - & - \\
\hline 1 & Glycerol & - & - & - \\
\hline 2 & Erythritol & - & - & - \\
\hline 3 & D-Arabinose & - & - & - \\
\hline 4 & L-Arabinose & + & + & - \\
\hline 5 & D-Ribose & + & - & - \\
\hline 6 & D-Xylose & + & - & - \\
\hline 7 & L-Xylose & - & - & - \\
\hline 8 & D-Adonitol & - & - & + \\
\hline 9 & Methyl $\beta-D-$ & - & + & + \\
\hline 10 & Xylopyranoside & & + & - \\
\hline 11 & D-Galactose & + & + & - \\
\hline 12 & D-Glucose & - & + & - \\
\hline 13 & D-Fructose & + & - & - \\
\hline 14 & D-Mannose & - & - & - \\
\hline 15 & L-Sorbose & - & - & - \\
\hline 16 & Dhomnose & - & - & \\
\hline 17 & Inositol & - & + & \\
\hline 18 & D-Mannitol & - & & \\
\hline
\end{tabular}




\begin{tabular}{|c|c|c|c|c|}
\hline 19 & D-Sorbitol & - & - & - \\
\hline 20 & $\begin{array}{c}\text { Methyl } \alpha \text {-D- } \\
\text { Mannopyranoside }\end{array}$ & - & + & - \\
\hline 21 & $\begin{array}{c}\text { Methyl } \alpha \text {-D- } \\
\text { Glucopyranoside }\end{array}$ & - & - & - \\
\hline 22 & N-Acetyl Glucosamine & + & + & + \\
\hline 23 & Amygdalin & - & + & - \\
\hline 24 & Arbutin & - & + & - \\
\hline 25 & Esculin Ferric citrate & + & + & + \\
\hline 26 & Salicin & - & + & - \\
\hline 27 & D-Celiobiose & - & + & - \\
\hline 28 & D-Maltose & + & + & - \\
\hline 29 & $\begin{array}{l}\text { D-Lactose (bovine } \\
\text { origin) }\end{array}$ & - & + & - \\
\hline 30 & D-Melibiose & + & + & - \\
\hline 31 & D-Saccharose(Sucrose) & - & + & + \\
\hline 32 & D-Trehalose & - & + & + \\
\hline 33 & Inulin & - & - & - \\
\hline 34 & D-Melezitose & - & - & + \\
\hline 35 & D-Raffinose & - & + & - \\
\hline 36 & Amidon (starch) & - & - & - \\
\hline 37 & Glycogen & - & - & - \\
\hline 38 & Xylitol & - & - & - \\
\hline 39 & Gentiobiose & - & + & - \\
\hline 40 & D-Turanose & - & - & - \\
\hline 41 & D-Lyxose & - & - & - \\
\hline 42 & D-Tagatose & - & - & - \\
\hline 43 & D-Fucose & - & - & - \\
\hline 44 & L-Fucose & - & - & - \\
\hline 45 & D-Arbitol & - & - & - \\
\hline 46 & L-Arbitol & - & - & - \\
\hline 47 & Potassium Gluconate & + & - & - \\
\hline 48 & $\begin{array}{c}\text { Potassium2- } \\
\text { KetoGluconate }\end{array}$ & + & - & - \\
\hline 49 & $\begin{array}{l}\text { Potassium 5- } \\
\text { ketoGluconate }\end{array}$ & + & - & - \\
\hline & Catalase test & -ve & $-\mathrm{ve}$ & $-\mathrm{ve}$ \\
\hline & $\begin{array}{c}\text { Identified } \\
\text { Lactobacillus spp. }\end{array}$ & L.brevis & L. brevis & L.fermentum \\
\hline
\end{tabular}


Table.4 NCBI GeneBank accession number of the identified Lactobacillus isolates

\begin{tabular}{|c|c|c|}
\hline Isolates & $\begin{array}{c}\text { Partially identified by } \\
\text { BLAST }\end{array}$ & $\begin{array}{c}\text { NCBI GeneBank accession } \\
\text { no. }\end{array}$ \\
\hline K38A & Lactobacillus brevis & KU529283 \\
\hline K20 & Lactobacillus fermentum & KU644579 \\
\hline RD10 & Lactobacillus brevis & KX572212 \\
\hline
\end{tabular}

Fig.1 Gram staining of the selected isolates

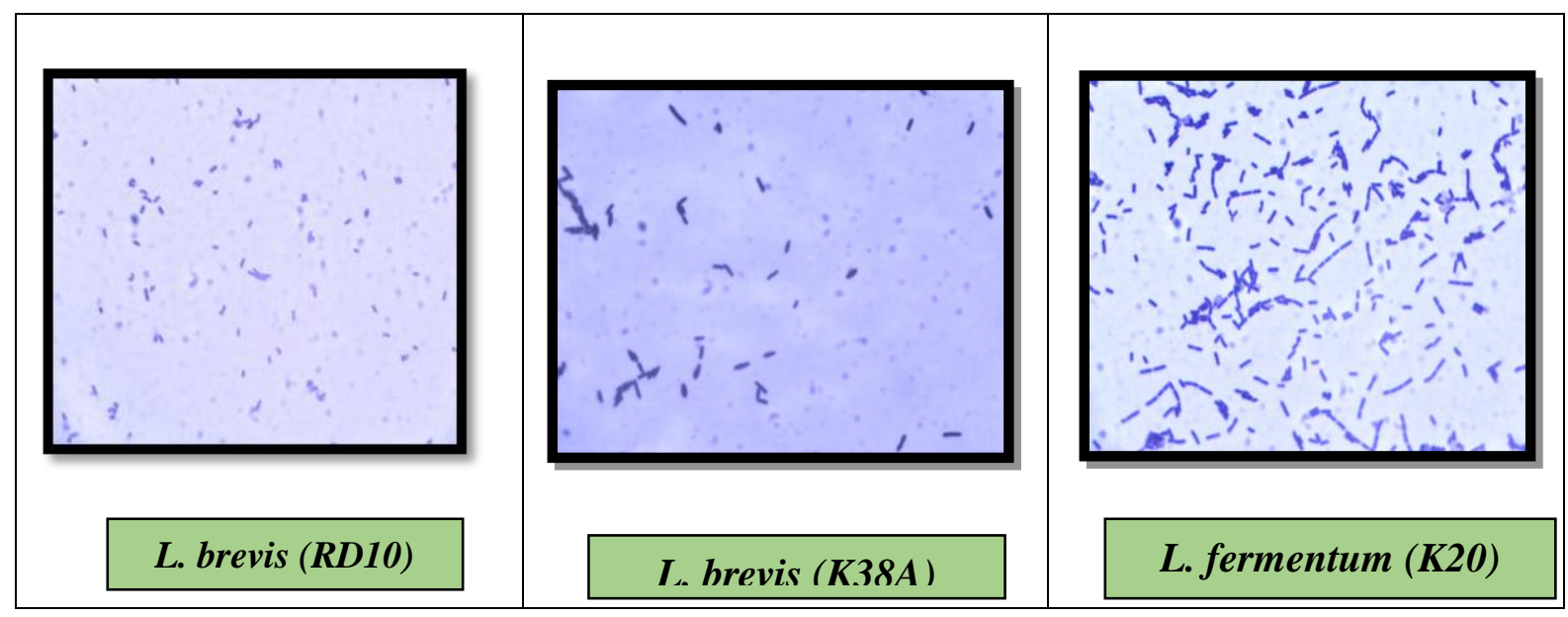

Fig.2 Biochemical analysis of the selected strain

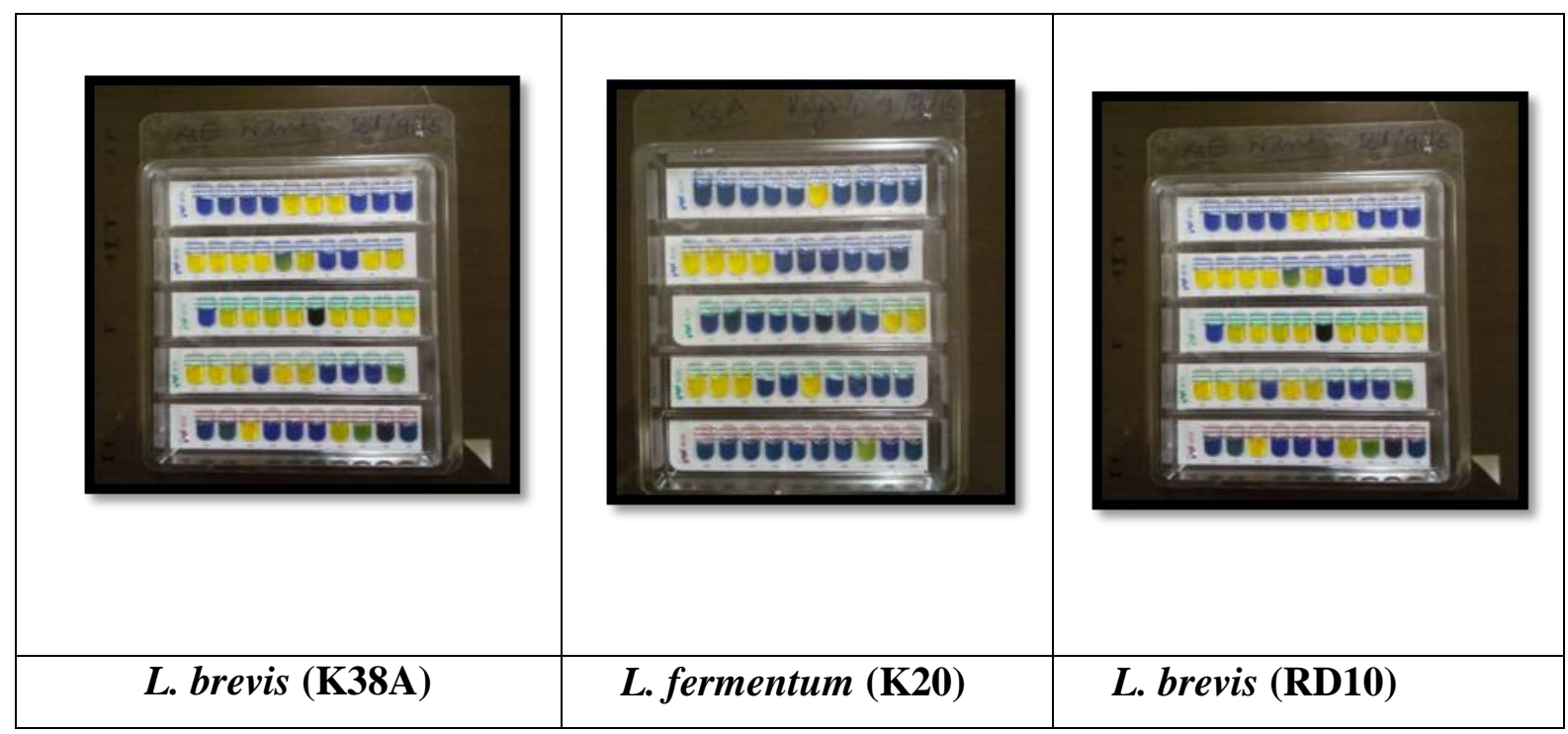


Fig.3 Rooted phylogenetic tree (UPGMA) for the strains of Lactobacillus from Tungrymbai

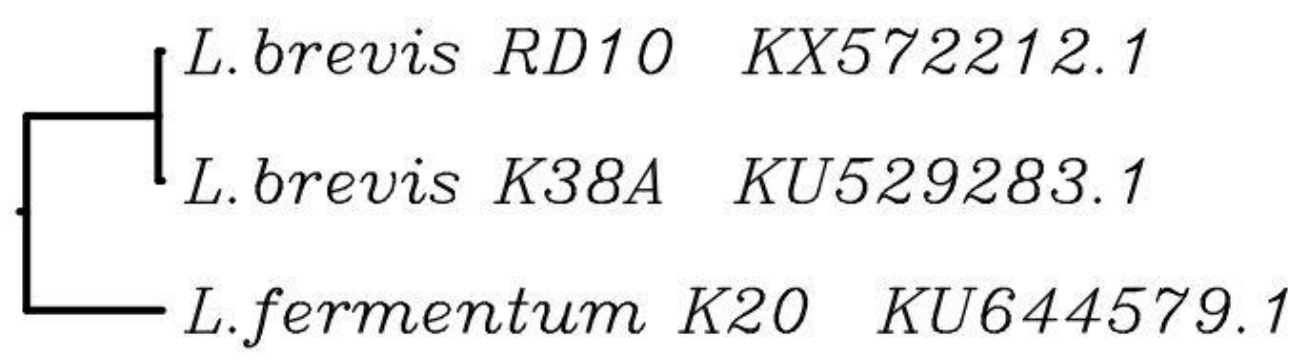

\section{Phylogenetic analysis}

To determine the closest known relatives of the partial $16 \mathrm{~S}$ rDNA sequences obtained, nucleotide database searches were performed in NCBI GenBank and later the sequences were analysed by multiple sequence alignment tools using the DNA alignment program MAFFT v6.864 to signify the evolutionary relatedness between the strains by UPGMA (Unweighted Pair Group Method with Arithmetic Mean)

Hence, from the phylogram (Figure 3), it can be stated that the two isolates of Lactobacillus brevis are closely related due to the sequence similarity match as well the nodal distance. The other distantly related isolate is of Lactobacillus fermentum that connects the branch of the two closely related Lactobacillus brevisstrains. Each node with descendants represents the inferred most recent common ancestor of the descendants which in this case is Lactobacillus.

The present study concluded that Lactobacillus spp. were predominant in microflora of Tungrymbai. The tentative phenotypic identification of the three isolates (RD10, K38A, and K20) were in good concordance with those by the genetic identification which derived that all the strains belonged to Lactobacillus spp. Further 16S rDNA sequence analysis of Lactobacillus strains confirmed the strains as Lactobacillus brevis (K38A and RD10) and Lactobacillus fermentum (K20). The evolutionary relatedness was checked by connecting them through a phlyogram. Further, the strains can be checked for their specific probiotic attributes that could be exploited for the development of value added fermented foods.

\section{Acknowledgement}

The authors are grateful to the Department of Biotechnology (DBT), Ministry of Science and Technology, New Delhi, India for the financial assistance under Twining Project 2013 in collaboration with Anand Agricultural University, Anand, Gujarat and North-Eastern Hill University, Tura Campus, Meghalaya.

\section{References}

Abbas, M.M., and Mahasneh, A.M. 2014. Isolation of Lactobacillus strains with probiotic potential from camel's milk. Afr. J. Microbiol. Res., 8(15): 16451655.

Buchanan R.E and Gibbons N.E. 1974. Bergy's Manual of Determentive Bacteriology.8th ed., Williams and Wilkins, Baltimore, 1268.

Clarridge, J.E. 2004. Impact of $16 \mathrm{~S}$ rRNA Gene Sequence Analysis for Identification of on Clinical Microbiology and Infectious Diseases. Clinic. Microbiol. Rev., 17(4): 840- 
862.

Guessas, B. and Khal, M. 2004. Characterization of lactic acid bacteria isolated from Algerian arid zone raw goat milk. Afr. J. Biotechnol., 3: 339342.

Harsmen, D., and Karch, H. 2004. 16S rDNA for diagnosing pathogens: a living tree. ASM new, 70: 19-24.

Kim, T.W., H.S. Song, and H.Y Kim, 2005. Distribution of dominant Bifdobacteria in the intestinal microflora of Korean adults and seniors, identifies by SDS-PAGE of whole cell proteins $16 \mathrm{~S}$ rDNA sequence analysis. J. Microbiol. Biotechnol., 15: 388-394.

Mahasneh, M.A., Hamdan S., Mahasneh A. S. 2015. Probiotic properties of Lactobacillus species isolated from local traditional fermented products. Jordan J. Biol. Sci., 8: 81-87.

Palys, T., Nakamura and Cohan, F.M. 1997.

Discovery and classification of ecological diversity in the bacterial world: the role of DNA sequence data. Int. J. Syst. Bacteriol., 47: 1145-1156.

Rahayu, T.H., Gandjar, I., Riani E., Djunaidah I.S. and Sjamsridzal, A. 2009. Identification and Phylogenetic Analysis of Bacterial Isolates from Litopeanaeus vannamei shrimp culture system and gut enviorment based on $16 \mathrm{~S}$ rRNA gene sequence data. Microbiol. Indones., 3(2): 56-60.

Rajendhran, J., Gunasekaran, P. 2011.
Microbial phylogeny and diversity: Small subunit ribosomal RNA sequence analysis and beyond. Microbiol. Res., 166: 99-110.

Palys, T., Nakamura and Cohan, F.M. 1997. Discovery and classification of ecological diversity in the bacterial world: the role of DNA sequence data. Int. J. Syst. Bacteriol., 47: 1145-1156.

Tamang, J.P., Chettri, R., Sharma, R.M. 2009. Indigenous knowledge of Northeast women on production of ethnic fermented soybean foods. Indian $J$. Tradit. Knowl., 8: 122-126.

Thokchom, S., Joshi, S.R. 2012. Antibiotic resistance and probiotic properties of dominant lactic microflora from Tungrymbai, an ethinic fermented soyabean food of India. J. Microbiol., 50(3): 553-559.

Tring, S.G. and P.Hugenholtz, 2008. A renaissance for the pioneering $16 \mathrm{~S}$ rRNA gen. Curr. Opin. Microbiol., 11: 442-446.

Trotoli, E. 2003. Impact of genotypic studies on mycobacterial taxonomy: the new mycobacteria of the 1990s. Clin. Microbiol. Rev., 16: 319-354.

Woese, C.R. 1987. Bacterial evolution. Microbiol. Rev., 51: 221-271.

Woese, C.R., E. Stackebrandt, T.J. Macke, and G.E. Fox. 1985. A phylogenetic definition of the major eubacterial taxa. Syst. Appl. Microbiol., 6: 143151.

\section{How to cite this article:}

Birendra Kumar Mishra, Subrota Hati, Sujit Das and Keyur Patel. 2017. Identification and Characterization of Lactobacillus isolates from fermented soya food "Tungrymbai", Meghalaya, India. Int.J.Curr.Microbiol.App.Sci. 6(2): 1103-1112. doi: http://dx.doi.org/10.20546/ijcmas.2017.602.124 